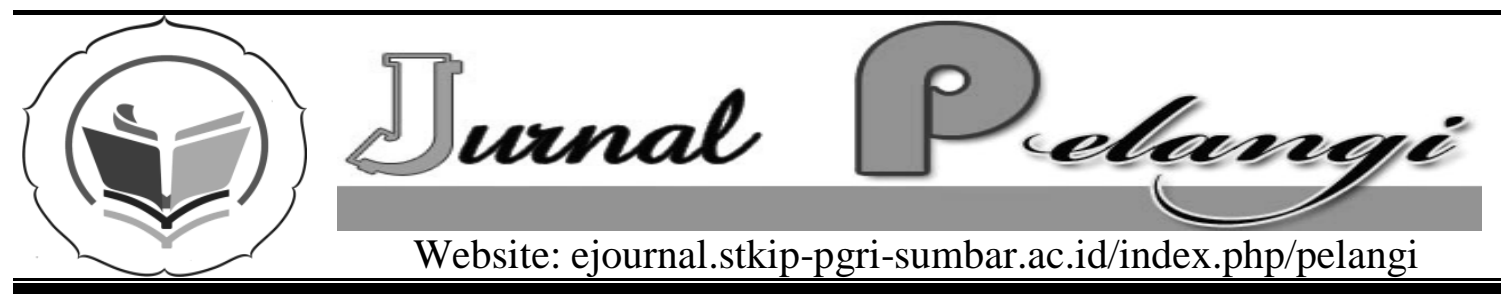

\title{
PENGARUH PENERAPAN METODE STRATAGEM MELALUI PEMBELAJARAN KOOPERATIF TERHADAP KEMAMPUAN KOMUNIKASI MATEMATIKA SISWA KELAS VIII SMP NEGERI 20 PADANG
}

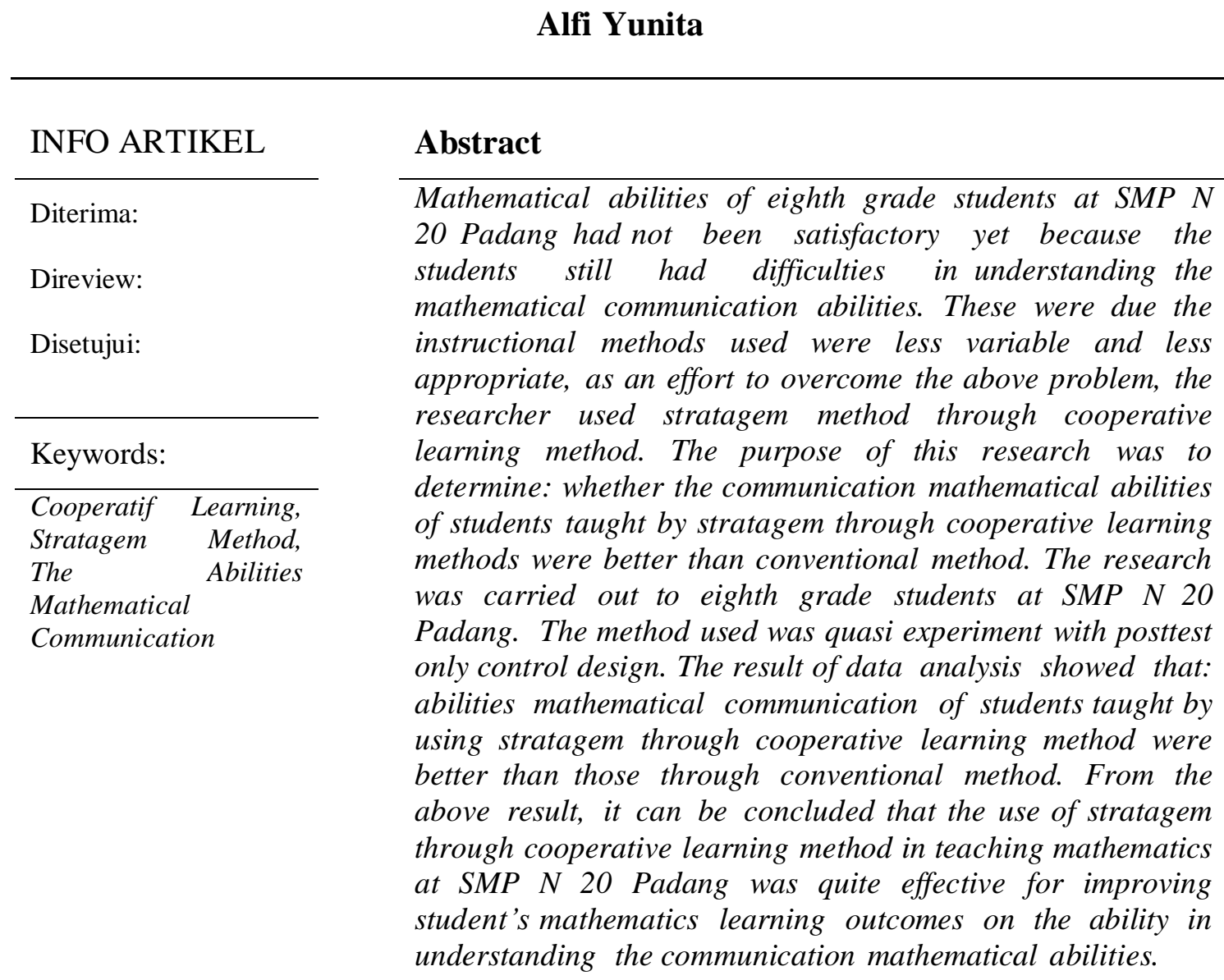

\section{PENDAHULUAN}

Matematika adalah ilmu dasar bagi dunia pendidikan karena matematika sangat mendukung untuk mempelajari ilmu-ilmu pengetahuan lainnya. Oleh sebab itu matematika merupakan pelajaran yang sangat penting diberikan di setiap jenjang pendidikan mulai dari tingkat sekolah dasar sampai perguruan tinggi. Adapun tujuan pembelajaran Matematika menurut Depdiknas (2003:1) sebagai berikut:

1. Melatih cara berfikir dan bernalar dalam menarik kesimpulan 
2. Mengembangkan aktifitas kreatif yang melibatkan imajinasi dan penemuan dengan mengembangkan pemikiran divergen, rasa ingin tahu, membuat prediksi dan dugaan serta mencoba-coba.

3. Mengembangkan

kemampuan menyampaikan informasi atau mengomunikasikan gagasan.

Untuk membantu siswa dalam menguasai matematika, perlu usaha maksimal agar tujuan pembelajaran matematika dapat tercapai seperti yang diharapkan. Salah satu usaha yang dapat dilakukan dalam pembelajaran matematika adalah guru seharusnya dapat memilih dan menggunakan metode pembelajaran yang tepat, sehingga siswa dapat memahami konsep matematika dengan baik.

Dari pengalaman dan pengamatan penulis pada saat mengajar matematika, ditemukan kondisi yang memperlihatkan kurangnya kemampuan matematika siswa, terutama pada kemampuan pemahaman konsep, kemampuan komunikasi matematika dan kemampuan pemecahan masalah. Hal tersebut dapat dilihat dari kondisi yang penulis jumpai, di antaranya adalah seperti berikut ini:

1. Ketika menyelesaikan persoalan matematika, sebagian siswa cenderung langsung memulai dengan formulasi-formulasi yang diperlukan tanpa mengikuti prosedur-prosedur yang seharusnya diikuti. Hal ini menunjukkan bahwa siswa masih belum memahami konsep matematika secara mendalam. Kondisi ini juga menunjukkan bahwa pemahaman siswa masih terfokus kepada contohcontoh yang diberikan.

2. Kemampuan siswa dalam menyelesaikan soal-soal komunikasi masih rendah. Hal ini ditandai dengan adanya siswa yang belum mampu untuk memberikan argumentasi dengan benar dan jelas tentang soalsoal yang mereka jawab, sehingga dalam menjawab persoalan matematika masih ada siswa yang belum mampu menggunakan bahasa komunikasi matematika yang mudah dimengerti dan dipahami.

3. Kemampuan siswa dalam menyelesaikan soal-soal pemecahan masalah masih rendah. Hal ini terbukti dari cara siswa menyelesaikan soal hanya terfokus kepada contoh-contoh penyelesaian soal yang diberikan pada saat belajar.

Untuk mengatasi permasalahan, dicoba menawarkan solusinya, yaitu dengan menggunakan metode stratagem melalui pembelajaran kooperatif dalam mengajar di kelas. Metode ini ditawarkan karena menurut Bell (dikutip oleh Munandir,

1991;488) "Metode stratagem yaitu permainan belajar akademik". Belajar melalui permainan adalah aktivitas yang menyenangkan, ringan dan bersifat kompetitif seperti yang dikemukakan oleh Romlah (1989:130) "Bermain merupakan cara belajar yang menyenangkan, karena dengan bermain bisa belajar sesuatu tanpa menyadarinya". Apa yang dipelajari itu disimpan dalam pikiran sehingga akan dipadukan menjadi suatu kesatuan dengan pengalaman lain yang kadangkadang tanpa disadari.

Dari penjelasan di atas dapat kita gambarkan bahwa belajar dengan menggunakan metode stratagem melalui pembelajaran kooperatif pada hakikatnya adalah belajar sambil bermain dalam berkelompok dan berdiskusi dalam memecahkan masalah tanpa ada ketegangan dalam belajar, sehingga siswa termotivasi dalam belajar dan membantu siswa dalam meningkatkan kemampuan pemahaman konsep, kemampuan komunikasi matematika dan 
kemampuan pemecahan masalah matematika siswa.

Untuk menunjang berjalannya proses pembelajaran kooperatif dengan baik diperlukan suatu panduan kegiatan, maka untuk itu guru perlu menyusun seperangkat lembaran kegiatan siswa (LKS) yang bisa memandu siswa dalam pemecahan masalah. Penggunaan LKS dalam model pembelajaran kooperatif ini diharapkan dapat membantu meningkatkan aktivitas siswa dalam proses pembelajaran karena LKS yang diberikan kepada siswa berupa suatu lembaran kerja yang harus dikerjakan oleh setiap siswa. Penemuan sendiri oleh siswa dalam menyelesaikan LKS akan menyebabkan siswa lebih banyak terlibat dalam proses pembelajaran. Dengan demikian diharapkan siswa akan terbantu dalam belajar matematika, seperti yang dikemukakan oleh Hadi Sukanto (1982:1) "lembaran kerja siswa dapat mengaktifkan siswa, membantu siswa menemukan dan membantu siswa mengembangkan keterampilan proses".

Berdasarkan uraian di atas, dilakukan penelitian mengenai pengaruh penerapan metode stratagem melalui pembelajaran kooperatif terhadap kemampuan matematika siswa kelas VIII SMP Negeri 20 Padang. Berpijak dari hal ini, permasalahan yang ingin dikaji dalam penulisan ini adalah apakah kemampuan komunikasi matematika siswa yang diajar dengan metode stratagem melalui pembelajaran kooperatif lebih baik dari pada siswa yang diajar dengan metode konvensional?

\section{LANDASAN TEORI}

A. Pembelajaran Matematika

terjadi suatu perubahan dalam individu yang belajar. Herman (1990:7) menyatakan bahwa apabila proses belajar matematika itu baik, dapat diharapkan hasil belajar peserta didik akan baik pula. Dengan kata lain apabila proses belajar matematikanya baik maka subjek yang belajar akan memahami matematika dengan baik pula dan dia akan lebih mudah mempelajari matematika selanjutnya. Oleh karena itu untuk mengajarkan pelajaran matematika, guru harus mencari metode mengajar yang cocok untuk penyajian materi agar siswa mudah memahaminya. Slameto (1995:64) mengatakan: "Metode mengajar adalah suatu cara atau jalan yang harus dilalui dalam mengajar". Metode mengajar guru yang kurang baik akan mempengaruhi belajar siswa yang tidak baik pula. Guru harus mampu menentukan metode mengajar serta alat bantu yang tepat yang sesuai dengan bahan yang disajikan juga sesuai dengan tujuan yang hendak dicapai sehingga materi mudah diterima siswa.

Berdasarkan kutipan di atas, dalam pembelajaran guru harus mampu memilih metode pembelajaran yang sesuai dengan materi yang akan dipelajari dan juga sesuai dengan tujuan pembelajaran. Ini berarti bahwa tidak mungkin guru hanya menggunakan satu metode saja dalam proses pembelajaran. Salah satu model pembelajaran yang dapat menggunakan metode bervariasi adalah model pembelajaran kooperatif.

\section{B. Pembelajaran Kooperatif \\ Pembelajaran}

kooperatif merupakan metode pembelajaran kelompok. Siswa dalam pembelajaran ini diharapkan dapat bekerjasama dan saling membantu sesama anggota kelompoknya untuk mempelajari suatu materi pelajaran dan mengerjakan tugastugas yang diberikan oleh guru. Anita (2002:12) menjelaskan bahwa sistem 
pengajaran yang memberikan kesempatan kepada anak didik untuk bekerjasama dengan sesama siswa dalam tugas-tugas yang terstruktur disebut sebagai sistem "pembelajaran gotong royong" atau cooperative learning”. Selanjutnya Anita (2002:6) juga menjelaskan bahwa dalam penerapan pembelajaran kooperatif dua atau lebih individu saling tergantung satu sama lain untuk mencapai satu penghargaan bersama. Mereka akan berbagi penghargaan tersebut seandainya mereka berhasil sebagai kelompok. Ini berarti bahwa anggota kelompok akan saling bekerjasama dan saling membantu untuk mempelajari suatu materi, melengkapi tugas-tugas serta menyelesaikan suatu masalah. Keberhasilan seseorang adalah keberhasilan kelompok.

Ciri-ciri pembelajaran kooperatif menurut Muslim Ibrahim (2001:6) sebagai berikut: 1) Siswa bekerja dalam kelompok secara kooperatif untuk menuntaskan materi pelajaran, 2) Kelompok dibentuk dari siswa yang berkemampuan tinggi, sedang dan rendah, 3) Bilamana mungkin, anggota kelompok berasal dari ras, budaya, suku, jenis kelamin berbeda-beda, 4) Penghargaan lebih berorientasi kelompok ketimbang individu.

Selanjutnya, menurut Muslim Ibrahim (2001:10) terdapat 6 langkah utama atau tahapan di dalam pembelajaran kooperatif yang terlihat dalam tabel berikut:

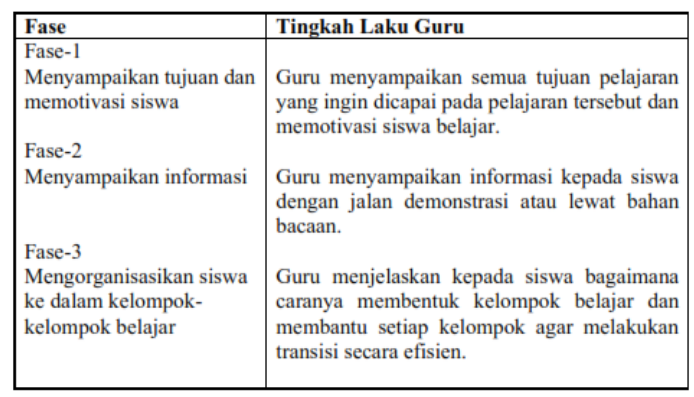

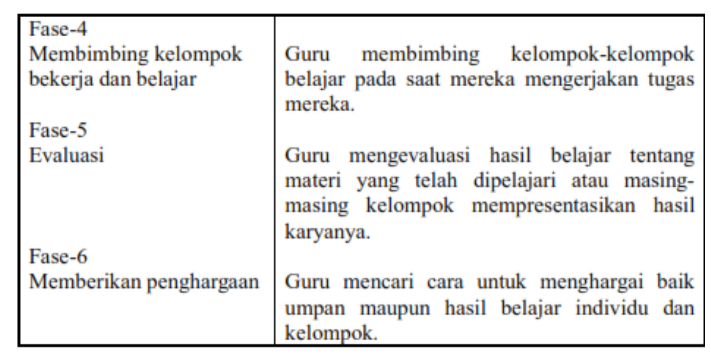

Dari kutipan di atas terlihat bahwa peranan guru dalam pembelajaran kooperatif sangat kompleks. Guru sebagai facilitator dan reinforcer dalam memberdayakan kerja kelompok siswa. Guru harus bisa memotivasi siswa untuk aktif dan berpartisifasi dalam kegiatan belajar.

\section{Metode Stratagem}

Metode stratagem merupakan salah satu bentuk permainan akademik yang dikembangkan oleh Bell (Munandir, 1991:488). Metode permainan ini mempunyai batas waktu dan aturan-aturan tertentu, dimana siswa dibagi menjadi beberapa kelompok yang saling berkompetisi untuk mencapai tujuan tertentu. Jumlah pemainnya terbatas dan lama permainannya juga terbatas. Permainan ini cocok dipakai untuk memotivasi siswa dalam belajar, terutama bila bahan pelajaran yang dipelajarinya kurang menarik. Permainan ini dikembangkan dengan maksud mengurangi tekanan karena belajar dalam menghadapi ujian maupun tidak dan untuk meningkatkan usaha siswa dalam mengerjakan soal-soal pelajaran sehingga dapat meningkatkan hasil belajar peserta.

Munandir

(1991:488)

menjelaskan bahwa cara belajar melalui permainan stratagem dalam pembelajaran kooperatif yaitu:

1. Permainan ini merupakan kegiatan belajar kooperatif yang terdiri dari 
2. 2 - 5 orang dimana mereka merupakan bankir dan juga pemain.

3. Menjawab pertanyaan secara bergiliran berdasarkan kartu-kartu soal.

4. Pemberian skor awal pada tiap kelompok.

5. Pemberian skor dalam setiap pertanyaan.

6. Setiap pertanyaan dijawab oleh kelompok selama 3 - 5 menit.

Pada permainan Stratagem ini yang ditetapkan sebagai bankir adalah guru dan sebagai pemain adalah siswasiswa yang dibagi menjadi beberapa kelompok. Kartu-kartu yang digunakan adalah berupa kartu pertanyaan dan kartu jawaban yang berukuran $5 \times 7,50$ $\mathrm{cm}$ dan pemberian skor pada tiap pertanyaan dibuat berdasarkan tingkat kesulitannya dan berdasarkan 6 langkah utama atau tahapan. Di dalam pembelajaran kooperatif dinyatakan bahwa guru menyampaikan informasi kepada siswa melalui demonstrasi atau lewat bahan bacaan, maka ditetapkan di dalam pembelajaran kooperatif ini menggunakan bacaan yang berupa Lembar Kerja Siswa (LKS).

\section{Metode Konvensional}

Metode konvensional adalah metode yang umum dipakai dalam pelaksanaan pembelajaran di kelas. Metode konvensional identik dengan metode pembelajaran dimana guru menjadi pusat dari kegiatan pembelajaran. Metode tersebut dikenal sebagai metode ceramah dan masih tetap digunakan dalam strategi belajar- mengajar. Metode ini paling tua, paling banyak dan paling sering dipakai dalam berbagai kesempatan. Di tengahtengah perkembangan teknologi komunikasi sekarang ini, metode ini masih tetap bertahan.
Jika dicermati, dalam penerapan metode konvensional, guru menjadi pusat dari kegiatan pembelajaran dan mempunyai keunggulan antara lain hemat dalam penggunaan waktu dan alat, organisasi kelas sederhana, mampu membangkitkan minat dan antusias siswa apabila sesuatu yang dilihat, didengar bisa menarik perhatian siswa. Sedangkan kelemahan metode ini antara lain guru sukar mengetahui sampai dimana murid-murid telah mengerti pembicaraannya, murid sering memberi pengertian lain dari hal yang dimaksud guru.

\section{E. Kemampuan Komunikasi Matematik}

Peraturan Pemerintah Republik Indonesia (PPRI) nomor 19 Tahun 2005 tentang Standar Nasional Pendidikan (2005:28) pada Bab VI, Standar Pendidik dan Tenaga Kependidikan pada pasal 28 ayat 3 menjelaskan "kompetensi sebagai agen pembelajar pada jenjang pendidikan dasar dan menengah serta pendidikan anak usia dini meliputi: a) kompetensi pedagogik; b) kompetensi kepribadian; c) kompetensi professional; dan kompetensi sosial". Pada bagian penjelasan dari pasal ini dinyatakan bahwa yang dimaksud dengan kompetensi sosial adalah kemampuan berkomunikasi dan bergaul secara efektif dengan peserta didik, semua pendidik dan masyarakat sekitar.

Secara umum komunikasi dipahami sebagai suatu bentuk aktivitas penyampaian informasi dalam suatu komunitas tertentu. Komunikasi dapat terjadi dua arah, satu arah atau multiarah, yaitu dari penyampai pesan kepada penerima pesan. Pada aktivitas komunikasi dalam kelompok bisa terdapat banyak penyampai dan penerima pesan, sehingga komunikasi ini merupakan aktivitas berbagi ide dan 
gagasan, curah pendapat, sumbang saran dan kerjasama dalam kelompok. Aktivitas semacam ini dapat mengasah kemampuan berkomunikasi atau kemampuan menyampaikan pemikiran tentang sesuatu hal bagi para pesertanya. Khususnya komunikasi dalam matematika adalah suatu aktivitas penyampaian dan atau penerimaan gagasan-gagasan matematika dalam bahasa matematika.

Romberg Chair dalam

Sumarmo (2002) mengatakan bahwa "salah satu aspek berpikir tingkat tinggi dalam matematika adalah komunikasi dalam matematika atau komunikasi matematik yang menghubungkan benda nyata, gambar dan diagram ke dalam ide matematik; menjelaskan ide, situasi dan relasi matematika secara lisan atau tulisan dengan benda nyata, gambar, grafik dan aljabar; menyatakan peristiwa sehari-hari dalam bahasa simbol matematika; mendengarkan, berdiskusi dan menulis tentang matematika; mencoba dengan pemahaman suatu presentasi matematika tertulis, membuat konjektur, menyusun argumen, merumuskan definisi dan generalisasi; menjelaskan dan membuat pertanyaan tentang matematika yang telah dipelajari.

Dari kedua uraian tentang komunikasi matematik siswa di atas tampak bahwa, komunikasi matematik dapat terjadi bila siswa belajar dalam kelompok. Setiap anggota kelompok mempunyai peluang yang cukup untuk menyampaikan gagasan atau pendapat dalam kelompoknya, sehingga prosedur berpikir yang dilakukannya dalam memecahkan masalah ataupun menyelesaikan tugas dapat terkomunikasikan dalam kelompoknya.

telah $\begin{gathered}\text { Selanjutnya siswa dikatakan } \\ \text { memiliki }\end{gathered}$ komunikasi matematik bilamana siswa telah menguasai indikator-indikator yang direkomendasikan NCTM (2000, standarts.nctm) sebagai berikut: 1) Dapat menyatakan ide matematik dengan lisan, tulisan, mendemonstrasikan dan menggambarkan dalam bentuk visual, (2) dapat memahami, menginterpretasikan dan menilai ide matematik yang disajikan dalam bentuk lisan, tulisan atau bentuk visual, (3) dapat menggunakan bahasa, notasi dan struktur matematik untuk menyajikan ide, menggambarkan hubungan pembuatan model".

Indikator komunikasi matematika menurut John (2008:5) adalah sebagai berikut: 1) Mengatur dan mengabungkan pemikiran matematika melalui komunikasi, 2) Mengkomunikasikan pemikiran matematika secara koheren dan jelas, 3) Menganalisa dan menilai pemikiran dan strategi matematika orang lain,

4) Menggunakan bahasa matematika untuk menyampaikan ide dengan tepat.

Berkaitan dengan komunikasi matematik atau komunikasi dalam matematika ini, Rahman (2008:684) menyatakan kemampuan yang tergolong pada komunikasi matematika di antaranya adalah: 1) Menyatakan suatu situasi, gambar, diagram, atau benda nyata ke dalam bahasa, simbol, idea, atau model matematik, 2) Menjelaskan idea, situasi, dan relasi matematika secara lisan atau tulisan, 3) Mendengarkan, berdiskusi dan menulis tentang matematika, 4) Membaca dengan pemahaman suatu representasi matematika tertulis, 5) Membuat konjektur, menyusun argumen, merumuskan definisi, dan generalisasi, 6) Mengungkapkan kembali suatu uraian atau paragraph matematika dalam bahasa sendiri.

Dari beberapa penjelasan di atas, dapat kita ambil suatu kesimpulan bahwa, siswa memiliki kemampuan 
komunikasi matematik jika memiliki kemampuan- kemampuan sebagai berikut: 1) Kemampuan menggambar, yaitu meliputi kemampuan siswa mengungkapkan ide-ide matematika ke dalam bentuk gambar, 2) kemampuan membuat pemodelan matematika, yaitu kemampuan membuat model matematika, 3) Kemampuan menulis, yaitu berupa kemampuan memberikan penjelasan dan alasan secara matematika dengan bahasa yang benar dan mudah dipahami.

Dari penjelasan-penjelasan tersebut, maka dalam penelitian ini siswa dikatakan memiliki kemampuan komunikasi matematik jika siswa memiliki kemampuan dalam mengkomunikasikan gagasan dengan simbol dan menuliskannya ke model matematika.

\section{METODOLOGI PENELITIAN}

\section{A. Jenis dan Alur penelitian}

Penelitian ini menggunakan pendekatan kuantitatif dalam bentuk Quasi Experiment Design. Rancangan penelitian yang digunakan adalah Posttest-Only Control Design yang terdiri dari dua kelompok. Variabel pada penelitian ini terdiri dari (a) variabel bebas yaitu metode pembelajaran, (b) variabel terikat yaitu kemampuan matematika yang meliputi pemahaman konsep, kemampuan komunikasi matematis, dan kemampuan pemecahan masalah.

\section{B. Populasi dan Sampel}

Populasi dalam penelitian ini adalah siswa kelas VIII tahun pelajaran 2010/2011 di SMP Negeri 20 Padang yang terdiri dari 8 kelas dengan jumlah siswa seperti terlihat pada Tabel 1 berikut ini.
Tabel 1. Jumlah siswa kelas VIII SMP Negeri 20 Padang

\begin{tabular}{|c|c|c|}
\hline No & Kelas & Jumlah Siswa \\
\hline 1. & VIII.1 & 39 \\
\hline 2. & VIII.2 & 37 \\
\hline 3. & VIII.3 & 34 \\
\hline 4. & VIII.4 & 40 \\
\hline 5. & VIII.5 & 33 \\
\hline 6. & VIII.6 & 36 \\
\hline 7. & VIII.7 & 35 \\
\hline 8. & VIII.8 & 39 \\
\hline
\end{tabular}

Teknik pengambilan sampel yang digunakan dalam penelitian ini adalah Purposive Sampling. Terpilihnya sebagai sampel adalah kelas VIII.1 dan kelas VIII.8 dengan pertimbangan guru yang mengajar pada kedua kelas ini adalah sama dan memberikan peluang kepada peneliti untuk melakukan penelitian di SMP Negeri 20 Padang. Dari hasil perhitungan dimana kedua kelas tersebut tidak terdapat perbedaan maka dipilihlah kelas VIII.1 sebagai kelas eksperimen dan kelas VIII.8 sebagai kelas kontrol setelah dilakukan uji kesamaan rata-rata.

\section{Definisi Operasional}

Untuk menggambarkan ruang lingkup yang menjadi batasan penelitian maka

dikemukakan definisi operasional sebagai berikut:

1. Metode Stratagem merupakan salah satu bentuk permainan akademik yang mempunyai batas waktu dan aturan-aturan tertentu, dimana siswa dibagi menjadi beberapa kelompok yang saling berkompetisi untuk menyelesaikan soal yang dibagikan berupa kartu soal, dan lamanya permainan juga ditentukan. Sedangakan Model Pembelajaran kooperatif adalah proses belajar mengajar yang dijalankan dengan cara mengelompokkan siswa ke dalam 
kelompok-kelompok kecil untuk memecahkan masalah dan tugastugas pembelajaran.

2. Metode konvensional merupakan metode pembelajaran yang berpola teacher-centered atau berpusat pada guru. Proses pembelajaran didominasi oleh guru dengan metode ceramah.

3. Hasil belajar kognitif merupakan skor tes yang diperoleh dalam mengukur kemampuan matematika siswa yang terdiri dari kemampuan pemahaman konsep, kemampuan komunikasi matematika dan kemampuan pemecahan masalah. Tes diberikan berbentuk tes essay.

4. Indikator pemahaman konsep pada penelitian ini adalah sebagai berikut: a) Menyebutkan dan menejelaskan konsep dengan benar, b) Menerapkan konsep secara benar, c) Memberikan contoh dari suatu konsep secara tepat.

5. Indikator komunikasi matematis pada penelitian ini adalah sebagai beriku: a) Menyajikan matematika secara tertulis, b) Menyajikan pernyataan matematika dengan gambar, c) Membuat pemodelan matematika.

6. Indikator pemecahan masalah pada penelitian ini adalah sebagai berikut: a) Mengidentifikasikan unsurunsur yang diketahui dari suatu permasalahan, b) Membuat perumusan dari permasalahan, c) Menentukan strategi yang tepat dalam menyelesaikan permasalahan.

Informan atau sumber data dari penelitian ini adalah guru kelas I SD Negeri Percobaan Padang yang akan dilihat proses pembelajarannya. Kegiatan yang dilihat yaitu pada saat mengikuti workshop, persiapan mengajar pada waktu mengikuti workshop serta proses pembelajaran setelah mengikuti workshop tersebut.

D.Pelaksanaan Pembelajaran Menggunakan Metode Stragem

Permainan stratagem di kelas eksperimen dilakukan dengan cara sebagai berikut:

1. Sepasang kelompok yang berkompetisi berhadap-hadapan.

2. Guru membagikan kartu soal dan jawaban kepada kelompok yang berbeda dalam pasangan permainan tersebut. Kartu jawaban diberikan dalam keadaan tertelungkup dan untuk menjaga kerahasiaan jawaban maka kartu jawaban disegel atau diklep.

3. Salah seorang anggota kelompok yang mendapat soal membuka soal dan membacakannya, kemudian tiap pasangan tersebut membahas soal. Tiap pasangan boleh mendapatkan bantuan dari teman sekelompoknya untuk menyelesaikan soal yang diberikan dan setiap siswa bertanggung jawab menyelesaikan soal tersebut bersama kelompoknya.

4. Jika kelompok penjawab (pemegang kartu soal) selesai menjawab soal sesuai dengan waktu yang telah ditentukan, maka kelompok pasangannya (pemegang kartu jawaban) membuka kartu jawaban dan menyesuaikannya dengan jawaban yang ada.

5. Jika kelompok penjawab menjawab dengan benar maka bankir mencatat penambahan skor kelompok yang diperoleh sesuai dengan skor soal, jika salah skor dikurangi sesuai dengan skor soal.

6. Jika kelompok penjawab menjawab salah dalam waktu tertentu tidak dapat menjawab, maka kelompok pasangannya berhak menjawab soal, jika jawabannya benar maka 
memperoleh skor setengah dari skor soal, jika salah skornya tidak dikurangi.

7. Selanjutnya permainan diulangi, guru membagikan kartu soal kepada kelompok yang tadinya mendapat kartu jawaban, demikian sebaliknya. Permainan dilakukan kembali sesuai dengan peraturan yang berlaku.

8. Siswa bersama-sama dengan panduan guru menyimpulkan materi yang dipelajari dan guru memberikan PR, dan meminta siswa untuk langsung duduk pada kelompok yang sama pada pertemuan selanjutnya.

9. Pada kelas kontrol dilakukan pembelajaran dengan metode konvensional.

Berikut dijelaskan proses pelaksanaan pembelajaran pada kelas kontrol, yaitu:

1. Siswa duduk secara klasikal.

2. Guru menyampaikan tujuan pembelajaran.

3. Guru menjelaskan materi, kemudian diberi contoh soal.

4. Guru meminta siswa untuk bertanya mengenai bagian yang tidak dimengerti, kemudian siswa diminta untuk menyelesaikan soalsoal yang ada pada buku sumber dan dibahas bersama-sama pada akhir pembelajaran.

5. Guru membimbing siswa membuat kesimpulan dan memberikan latihan untuk dikerjakan di rumah (PR).

E. Instrumen Penelitian

Data dalam penelitian ini diperoleh dengan menggunakan instrumen

penelitian berupa kemampuan komunikasi matematika siswa yang berbentuk essay.

Penyusunan soal ini menuntut siswa memberikan jawaban berupa kemampuan komunikasi matematika seperti yang telah dijelaskan pada indikator- indikator kemampuan komunikasi. Kemampuan komunikasi matematika siswa diukur melalui dua butir soal essay, yaitu pada soal nomor 2 dan 4. Penyusunan dan pemberian skor butir soal tes kemampuan komunikasi dapat dilihat pada Tabel 2 .

Tabel 2. Kriteria Penilaian Kemampuan Komunikasi Matematika

\begin{tabular}{|c|l|l|l|}
\hline Skor & \multicolumn{1}{|c|}{ Menulis } & \multicolumn{1}{|c|}{ Menggambar } & \multicolumn{1}{|c|}{ Memodelkan } \\
\hline $\mathbf{0}$ & \multicolumn{3}{|c|}{ Tidak ada jawaban } \\
\hline 1 & $\begin{array}{l}\text { Hanya sedikit dari } \\
\text { penjelasan yang } \\
\text { benar }\end{array}$ & $\begin{array}{l}\text { Hanya sedikit dari } \\
\text { gambar yang benar }\end{array}$ & $\begin{array}{l}\text { Hanya sedikit dari } \\
\text { model matematika } \\
\text { yang benar }\end{array}$ \\
\hline 2 & $\begin{array}{l}\text { Penjelasan kurang } \\
\text { lengkap dan } \\
\text { argument kurang } \\
\text { tepat }\end{array}$ & $\begin{array}{l}\text { Melukiskan gambar } \\
\text { kurang lengkap dan } \\
\text { benar }\end{array}$ & $\begin{array}{l}\text { Membuat model } \\
\text { matematika } \\
\text { dengan benar, } \\
\text { namun salah dalam } \\
\text { mendapatkan } \\
\text { solusi }\end{array}$ \\
\hline 3 & $\begin{array}{l}\text { Penjelasan hampir } \\
\text { lengkap dan } \\
\text { argument kurang } \\
\text { tepat }\end{array}$ & $\begin{array}{l}\text { Melukiskan gambar } \\
\text { hampir lengkap dan } \\
\text { benar }\end{array}$ & $\begin{array}{l}\text { Membuat model } \\
\text { matematika } \\
\text { hampir benar dan } \\
\text { kemudian } \\
\text { mendapatkan }\end{array}$ \\
\hline 4 & $\begin{array}{l}\text { Penjelasan lengkap, } \\
\text { jelas dan disertai } \\
\text { argument yang tepat }\end{array}$ & $\begin{array}{l}\text { Melukiskan gambar } \\
\text { secara lengkap dan } \\
\text { benar }\end{array}$ & $\begin{array}{l}\text { Membuat model } \\
\text { matematika } \\
\text { lengan benar dan } \\
\text { kemudian } \\
\text { mendapatkan } \\
\text { solusi secara } \\
\text { lengkap }\end{array}$ \\
\hline
\end{tabular}

Dari Tabel 2, ada tiga aspek yang diukur untuk mengetahui kemampuan komunikasi siswa, yaitu meyajikan matematika secara tertulis, dengan gambar, dan membuat pemodelan matematika. Tujuan pemberian skor seperti ini adalah agar setiap jawaban yang diberikan siswa mendapatkan penilaian yang sesuai dengan jawaban yang diberikan.

\section{F. Teknik Analisis Data}

Analisis data dilakukan untuk
menguji hipotesis
dirumuskan. Untuk menentukan uji


statistik yang digunakan, terlebih dahulu ditentukan normalitas data dan homogenitas variansi. Uji normalitas bertujuan untuk mengetahui apakah masing-masing kelompok data berdistribusi normal atau tidak. Uji homogenitas variansi bertujuan untuk mengetahui apakah variansi kedua kelompok sampel sama atau berbeda.

Selanjutnya dilakukan pengujian hipotesis. Uji hipotesis dilakukan setelah dilakukan uji normalitas dan uji homogenitas terhadap kelas sampel. Untuk kedua kelompok data yang berdistribusi normal dan variansi homogen maka rumus yang digunakan adalah:

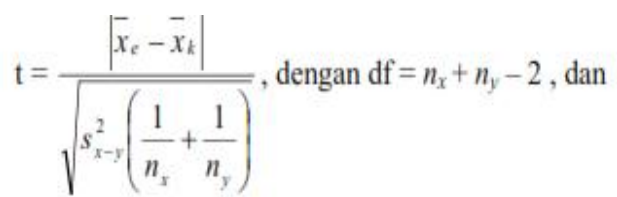

$$
\mathrm{s}_{x-y}^{2}=\frac{s_{x}^{2}\left(n_{x}-1\right)+s_{y}^{2}\left(n_{y}-1\right)}{n_{x}+n_{y}-2}
$$

$$
\begin{aligned}
& \text { Keterangan: } \\
& \bar{x}_{1}=\text { rata }- \text { rata kelas eksperimen } \\
& \bar{x}_{2}=\text { rata }- \text { rata kelas kontrol } \\
& S_{1}^{2}=\text { simpangan baku kelas eksperimen } \\
& S_{2}^{2}=\text { simpangan baku kelas kontrol } \\
& n_{1}=\text { jumlah siswa kelas eksperimen } \\
& n_{2}=\text { jumlah siswa kelas kontrol }
\end{aligned}
$$

Kriteria pengujiannya adalah tolah $\mathrm{H} 0$ jika thitung $>\mathrm{t}_{(1-\mathrm{a})}$ dengan $\mathrm{df}=\left(\mathrm{n}_{1}-\mathrm{n}_{2}-2\right)$ selain itu HO diterima (Sudjana, 1992:239).

\section{HASIL PENELITIAN DAN}

\section{PEMBAHASAN}

\section{A. Hasil Penelitian \\ 1. Deskripsi Data}

Kemampuan Komunikasi Matematis Setelah dilakukan pengolahan data hasil tes kemampuan komunikasi matematis pada kedua kelompok, diperoleh skor tertinggi, skor terendah, skor rata-rata, dan standar deviasi yang disajikan pada diagram batang di bawah ini.

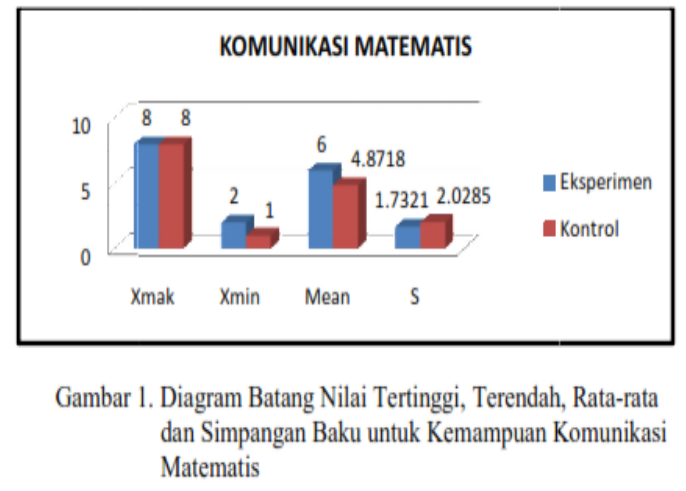

Pada Gambar 1 memperlihatkan rata-rata kemampuan komunikasi matematis siswa yang menggunakan metode stratagem melalui pembelajaran kooperatif lebih tinggi daripada yang menggunakan metode konvensional. Berdasarkan data simpangan baku, skor kemampuan komunikasi matematis siswa yang menggunakan metode konvensional menyebar dibandingkan dengan yang menggunakan metode stratagem melalui pembelajaran kooperatif. Hal ini menunjukkan, bahwa sebaran skor kemampuan komunikasi matematis tersebut pada kelas eksperimen lebih memusat ke rata-rata dibandingkan kelas kontrol.

2. Pengujian Persyaratan Analisis

a. Uji Normalitas

Hasil perhitungan uji normalitas untuk tiap kelompok data dapat dilihat pada Tabel 3 .

\section{Tabel 3. Hasil Uji Normalitas untuk setiap kelompok}

Tabel 3. Hasil Uji Normalitas untuk setiap kelompok

\begin{tabular}{|l|l|l|l|l|}
\hline Aspek & Perlakuan & Lhitung & Ltabel & Normalitas \\
\hline \multirow{2}{*}{$\begin{array}{l}\text { Kemampuaan } \\
\text { Komunikasi Matematis }\end{array}$} & Eksperimen & 0,1280 & 0,141 & Normal \\
\cline { 2 - 5 } & Kontrol & 0,1022 & 0,141 & Normal \\
\hline
\end{tabular}

Berdasarkan hasil ujian normalitas pada Tabel 3 diperoleh nilai $\mathrm{L}_{\text {abbel }}>\mathrm{L}_{\text {hitung }}$ sehingga dapat disimpulkan bahwa kemampuan komunikasi matematis siswa berdistribusi normal. 
b. Uji Homogenitas Variansi

Hasil perhitungan

uji homogenitas variansi untuk setiap kelompok dapat dilihat pada Tabel 4.

Tabel 4. Hasil Uji Homogenitas Variansi

\begin{tabular}{|l|l|l|l|}
\hline Aspek & $F_{\text {hitung }}$ & $F_{\text {tabel }}$ & Homogenitas \\
\hline $\begin{array}{l}\text { Kemampuan Komunikasi } \\
\text { Matematis }\end{array}$ & 1,37 & 1,72 & Homogen \\
\hline
\end{tabular}

Dari hasil uji homogenitas variansi pada Tabel 8 tersebut, diperoleh variansi data untuk kemampuan komunikasi matematis antara kelompok eksperimen dan kontrol, menunjukkan bahwa Fhitung $<$ Ftabel pada $=0,05$. Hal ini berarti variansi kedua kelompok adalah homogen.

\section{c. Pengujian Hipotesis}

Setelah dilakukan perhitungan perbedaan rata-rata menggunakan uji $\mathrm{t}$ diperoleh thitung $=2,64$, hasil yang diperoleh lebih besar dari ttabel untuk $=0,05$ yaitu 1,67, sehingga dapat disimpulkan HO ditolak. Hal ini berarti, kemampuan komunikasi matematis siswa yang diajar dengan metode stratagem melalui pembelajaran kooperatif lebih baik daripada kemampuan komunikasi matematis siswa yang diajar dengan metode konvensional.

\section{B. Pembahasan}

Hasil Belajar pada Aspek Kemampuan Komunikasi Matematis. Dari uji statistik terhadap perbedaan rata-rata memberikan hasil yang signifikan. Dengan kata lain, kemampuan komunikasi matematika siswa yang diajar dengan metode stratagem melalui pembelajaran kooperatif berbeda dengan siswa yang diajar dengan metode konvensional.
Hal ini diduga karena dalam pembelajaran dengan metode stratagem siswa berani menyampaikan gagasan atau ide kepada teman sekelompoknya dalam menjawab soal-soal yang ada pada LKS dan di kartu soal yang diberikan oleh guru. Dengan metode stratagem siswa dapat melakukan diskusi dan saling menanyakan sesuatu yang belum dimengerti sambil bermain sama teman sekelompoknya dimana dalam metode stratagem ini siswa tidak begitu tertekan dalam belajar. Hal ini sesuai dengan teori Tatik (1989:130) yang menyatakan "permainan merupakan suatu aktifitas yang menyenangkan, ringan dan bersifat kompetitif, atau kedua-duanya". Di samping itu, pada pembelajaran dengan metode stratagem ini terjadi komunikasi dua arah. Mereka dapat menyelesaikan soal-soal dengan bekerja sama, berdiskusi dalam kelompok yang heterogen. Siswa yang pandai menjelaskan pada temanteman yang belum paham dalam kelompoknya.

Melalui pembelajaran kooperatif, siswa diberi kesempatan yang lebih luas untuk dikenali, baik dalam kelompoknya maupun dalam pembelajaran. Siswa lebih berani mengemukakan ide yang ada dalam pikirannya karena mereka belajar dalam kelompok. Setiap siswa bebas memperlihatkan peran sertanya dalam mengemukakan gagasan dan ide serta menanyakan hal-hal yang belum mereka pahami. Siswa juga bebas mengkomunikasikan pendapatnya secara klasikal karena dalam pelaksanaan pembelajaran kooperatif siswa diminta untuk menjelaskan kembali materi yang belum dimengerti oleh siswa yang lemah. Dengan demikian siswa merasa lebih bebas dalam mengkomunikasikan ideide yang ada. 
Dalam proses pembelajaran yang berlangsung selama penelitian, siswa mulai terbiasa untuk menyampaikan ide dan gagasannya sehingga mereka tidak mengalami kesulitan dalam menulis dan mengkomunikasikan jawaban dari soal yang diberikan. Kondisi ini berdampak positif terhadap hasil belajar siswa pada aspek komunikasi khususnya komunikasi menjadi lebih baik.

Sementara itu, pada kelas control yang menerapkan metode konvensional, hal yang sering terjadi adalah komunikasi satu arah. Siswa hanya terbiasa menunggu penjelasan dari guru. Siswa tidak punya inisiatif untuk melakukan komunikasi yang berhubungan dengan materi pembelajaran yang sedang berlangsung. Siswa mengalami kesulitan dalam mengkomunikasikan ide karena mereka khawatir jawaban yang akan mereka kemukakan salah. Hanya beberapa siswa saja yang mampu berkomunikasi, itupun dilakukan dengan menanyakan langsung pada guru.

\section{KESIMPULAN DAN SARAN}

\section{A. Kesimpulan}

Penelitian ini merupakan penelitian yang membandingkan penggunaan dua metode pembelajaran, yaitu metode stratagem melalui pembelajaran kooperatif dan metode konvensional. Berdasarkan analisa data yang telah dikemukakan, diperoleh kesimpulan bahwa kemampuan komunikasi matematis siswa yang diajar dengan metode stratagem melalui pembelajaran kooperatif lebih baik daripada kemampuan komunikasi matematis siswa yang diajar dengan metode konvensional.

Dari hasil analisis data di atas dapat disimpulkan bahwa penggunaan metode stratagem melalui pembelajaran kooperatif pada mata pelajaran matematika pokok bahasan teorema Pythagoras di SMP Negeri 20 Padang ternyata cukup efektif untuk meningkatkan hasil belajar matematika siswa pada kemampuan komunikasi matematis. Keuntungan menggunakan metode stratagem melalui pembelajaran kooperatif adalah materi pelajaran dikaitkan dengan suatu permainan dimana siswa bersaing dalam suatu kompetisi untuk mendapatkan suatu penghargaaan dan dalam pembelajaran kooperatif adanya saling ketergantungan positif, saling membantu, saling memberikan motivasi sehingga ada interaksi positif, sedangkan peran guru sebagai bankir dalam suatu permainan dan memberikan arahan pada siswa.

\section{B. Saran}

Berdasarkan kesimpulan di atas, maka peneiti mengemukakan beberapa saran antara lain:

1. Bagi guru matematika khususnya dan guru mata pelajaran lain umumnya dapat menggunakan metode stratagem melalui pembelajaran kooperatif sebagai alternatif untuk meningkatkan aktifitas belajar siswa dan hasil belajar siswa.

2. Kepada peneliti lanjutan yang ingin melakukan penelitian serupa dapat mencobakan pada tempat dan materi yang berbeda dan mengontrol variabel-variabel lain yang ikut mempengaruhi kemampuan matematika siswa serta menyertakan angket aktifitas siswa untuk melihat aktivitas siswa selama penerapan metode pembelajaran ini. 


\section{DAFTAR PUSTAKA}

Anita Lie. 2002. Cooperative Learning. Jakarta: Grasindo.

Depdiknas. 2003. Penyusunan Butir Soal dan Instrumen Penilaian. Jakarta: Dikdasmen.

Herman Hudoyo. 1990. Belajar Mengajar Matematika. Jakarta: Dirjen Dikti P2LPT

John A. 2008. Matematika Sekolah Dasar dan Menengah. Jakarta: Erlangga. Munandir. 1991. Belajar dan Membelajarkan. Jakarta: Rajawali Press.

Muslim Ibrahim, dkk. 2001. Pembelajaran Kooperatif. Surabaya: University Press.

Tatiek Romlah. 1989. Teori dan Praktek Bimbingan Kelompok. Jakarta: Dikti LP3.

Rahman Nata Wijaya. 2008. Rujukan Filsafat, Teori, dan Praksis Ilmu Pendidikan. Bandung: UPI Press.

Slameto. 1995. Belajar dan Faktor-faktor yang Mempengaruhinya. Jakarta: Bumi Aksara

The Nasional Council of Teacher of Mathematic (NCTM). Principle and

Standards for School Mathematic. Reston, VA. (http://standards.nctm.org).

Utari Sumarmo. 2002. Pengukuran Evaluasi dalam Pendidikan. UPI Bandung. PRRI. No. 19 Tahun 2005 